Working Paper in Economics No. 761

\title{
Chinese aid and local ethnic identification
}

\author{
Ann-Sofie Isaksson
}

Department of Economics, April 2019 


\title{
Chinese aid and local ethnic identification
}

\begin{abstract}
Ann-Sofie Isaksson
Abstract: Recent empirical evidence suggests that Chinese development finance may be particularly prone to elite capture and patronage spending. If aid ends up in the pockets of political elites and their ethno-regional networks, this may exacerbate grievances based in horizontal inequalities. Against this background, the present study investigates whether the implementation of Chinese development projects fuels local ethnic identities. A new geo-referenced dataset on the subnational allocation of Chinese development finance projects to Africa over the 2000-2014 period is geographically matched with survey data for 94,954 respondents from 18 African countries. The identification strategy consists in comparing sites where a Chinese project was under implementation at the time of the interview, to sites where a Chinese project will appear subsequently but where implementation had not yet started at the time of the survey. While suggesting substantial country variation, the empirical results indeed suggest that, on average, living near an ongoing Chinese project fuels ethnic identification. I consider two mechanisms possibly underlying this result. First, competition for the inflow of resources that aid constitutes could mobilize ethnic identities across the board. Second, perceptions of ethnically biased aid may fuel ethnic identities in groups perceiving themselves as disadvantaged. Two observations speak in favour of the latter mechanism. First, the estimated effect is not uniform across groups, but driven by people belonging to the out-group. Second, there is no indication of an equivalent pattern when considering development projects of other donors. Replicating the key analysis for World Bank projects as well as for other bilateral donors, the results in fact indicate the reverse, i.e. that living near an ongoing as opposed to a future project comes with weaker ethnic identification.
\end{abstract}

JEL classification: F35, O19, O55

Keywords: China, aid, ethnic identities, Africa

\section{Introduction}

In 2010 China's foreign minister visited Yoni, a small village in Sierra Leone, with a grand school-building plan. While Sierra Leone could certainly use more schools, "some wondered why the Chinese chose the middle of the bush for the project" (The Economist, 2017). As it turns out, Yoni is the home village of Ernest Bai Koroma, Sierra Leone's president at the time. By a similar coincidence, of the three primary schools constructed with Chinese funds in rural Tanzania, one was built in the then President Jakaya Kikwete's hometown of Msoga (Hodzi, 
2017). Around the same time, in Namibia, Chinese scholarships went to children of top ministers and public officials, reigniting a debate that China uses its development finance "to create elite alliances and ease the approval of no-bid contracts" (The New York Times, 2009). These are not isolated incidents; the emergence of China as a key development partner in Africa has been the subject of much controversy (see e.g. the discussion in Tull, 2006; Kaplinsky et al., 2007; Naím, 2007; Penhelt, 2007; Bräutigam, 2009; Marantidou and Glosserman, 2015), not least for the alleged tendency of funds to end up in the pockets of political elites. Indeed, recent empirical evidence back up the anecdotal reports, suggesting that Chinese aid may be particularly easy to exploit for politicians who are engaged in patronage politics (Dreher et al., 2016).

In the African context, where patronage politics is commonly suggested to have an ethnic dimension (see e.g. Lemarchand, 1972; Wantchekon, 2003; Lindberg and Morrison, 2008), this raises questions regarding potentially important externalities of aid. In particular, if development finance ends up in the pockets of political elites and their ethno-regional networks, does this exacerbate ethnic grievances and contribute to ethnic mobilization? Against this background, the present study investigates whether Chinese development projects fuel local ethnic identities in African partner countries.

Until recently, studying the motivations behind and effects of Chinese development finance has been very difficult since the Chinese government, unlike the OECD-DAC donors, does not routinely publish information on its foreign assistance. However, with a new comprehensive dataset on Chinese Official Finance to Africa issued by the AidData research laboratory (Bluhm et al., 2018), systematic quantitative analysis of Chinese aid flows is now possible. Using this data, Dreher et al. (2016) find that Chinese development finance is disproportionately allocated to the birth regions of African leaders and, less clearly so, to areas populated by individuals who share their ethnicity. Replicating their analysis for World Bank aid, they find no evidence of corresponding regional or ethnic favoritism.

Two mechanisms through which Chinese development projects may make ethnic identities more salient are considered. First, in line with findings suggesting that ethnic identities are mobilized by political competition in the pursuit of resources (Eifert et al., 2010), competition for the inflow of resources that aid constitutes could mobilize ethnic identities across the board. Second, considering the recent evidence suggesting that Chinese development finance is particularly prone to elite capture and possible ethnic bias (Dreher et al., 2016), perceptions of ethnically biased aid may fuel ethnic identities in groups perceiving themselves as disadvantaged. 
Due to the likelihood of feeding into horizontal inequalities, ethnically biased aid is problematic. Horizontal inequalities - or inequalities between groups defined culturally, e.g. in terms of ethnic, religious or regional identity - matter both for individual well-being and instrumentally, for economic efficiency and social stability (Stewart et al., 2005). If membership of a group is part of a person's identity (see e.g. Akerlof and Kranton, 2000), their well-being will not only depend on individual circumstances, but also on how well their group is doing. Instrumentally, group inequalities may give rise to grievances that stimulate social unrest and conflict that undermine development efforts.

The concern that aid may exacerbate group inequalities, either because the donor's aid allocation decisions in themselves lead to a distribution of resources that worsens these inequalities or because elite capture of aid during the implementation phase has a similar effect (Brown et al., 2010), is not unique to Chinese aid. Indeed, empirical studies on sub-national aid allocation patterns of other donors often point to insufficient targeting of poor areas (see e.g. Powell and Findley, 2012; Öhler and Nunnenkamp, 2014; Briggs, 2017) as well as elite capture of aid (se e.g. Briggs, 2014; Jablonski, 2014; Dreher et al., 2016).

However, a number of commonly suggested features of Chinese development finance make it particularly relevant to study in this context. To begin with, the demand-driven nature of the Chinese aid allocation process (Brautigam, 2011; Dreher et al., 2016) and China's policy of non-interference in the domestic affairs of partner countries (State Council, 2014) arguably make it prone to elite capture and possible ethnic bias. Furthermore, rather than broad-based development projects established in country poverty reduction strategies, it is often suggested that China tends to finance highly visible prestige projects benefiting a select few (see e.g. Tull, 2006). Citizens in the local area are thus likely to observe the concerned development project being implemented without necessarily getting a share of the rewards, which may lead to perceptions of unfair treatment.

The study asks whether the implementation of Chinese development projects fuels ethnic identities near project sites, whether the effect is uniform across groups, and whether China stands out from other donors in this respect. To this end, a new geo-referenced dataset on the subnational allocation of Chinese development finance projects to Africa over the 2000-2014 period is geographically matched with 94,954 respondents from three Afrobarometer survey waves across 18 African countries. The estimation strategy to account for the endogenous placement of Chinese project sites consists in comparing the estimated effect of living near a site where a Chinese project was under implementation at the time of the interview, to that of living near a site where we know a Chinese project will appear subsequently. 
The empirical results indeed suggest that living near an ongoing Chinese project fuels ethnic identities. The effect is not uniform though, but driven by people who belong to the outgroup. The fact that the effect is only present among non-coethnics of the country president may signal that it is driven by ethnic grievances originating in perceived ethnic bias rather than ethnic competition for resources more generally. Furthermore, a comparison across donors reveals that Chinese development projects stand out from those of other influential donors in terms of fueling ethnic identities. If ethnic identities were mobilized by competition for the inflow of aid funds more broadly, one would expect the hypothesized pattern observed for China to be similar across donors. Hence, this too seemingly speaks against the general ethnic competition mechanism.

Replicating the key analysis for World Bank projects as well as for other bilateral donors the results in fact indicate the reverse, i.e. that living near an ongoing as opposed to a future project comes with weaker ethnic identification. Moreover, this effect is uniform across in- and out-group, thus providing no indication of differential experiences across ethnic groups. This suggestive finding opens for interesting future research: can aid projects, if implemented in an ethnically neutral fashion, in effect act to bring people together, across ethnic group lines?

Being the first effort to systemically investigate the effects of development projects on local ethnic identities in African partner countries, the study makes two principal contributions. First, it contributes directly to the literature on ethnic mobilization in Africa (e.g. Posner, 2003; Posner, 2004; Eifert et al., 2010). Eifert, Miguel and Posner (2010) find that the degree of ethnic identification in Africa varies considerably over time and is influenced by political competition. The present study brings this thinking to the aid literature, where a similar argument can be made for ethnic identities reacting to the infusion of donor funds. As such, it also adds to a broader literature on ethnic politics in Africa (see e.g. Lemarchand, 1972; Wantchekon, 2003; Lindberg and Morrison, 2008; Franck and Rainer; 2012; Hodler and Rachky, 2014; Burgess et al., 2015; Ahlerup and Isaksson, 2015; Kramon and Posner, 2016; Isaksson and Bigsten, 2017).

Second, it contributes to the emerging literature evaluating the sub-national allocation and impacts of aid (e.g. Francken et al., 2012; Nunnenkamp et al., 2012; Powell and Findley, 2012; Briggs, 2014; Jablonski, 2014; Öhler and Nunnenkamp, 2014; Berlin et al., 2017; Briggs, 2017). In particular, it adds to the recent strand of this literature focusing on the allocation and local externalities of Chinese aid (Dreher et al., 2016; Brazys et al., 2017; Bluhm et al., 2018; Isaksson and Kotsadam, 2018a,b). As noted by Bluhm et al. (2018) an important question that remains unanswered in this strand of literature is whether and to what extent Chinese 
development projects widen or narrow inequalities in poor countries. Bluhm and co-authors find that Chinese development projects in general, and Chinese transportation projects in particular, reduce spatial inequality measured in terms of night time light. They do not, however, consider inequalities across ethnic groups.

\section{Chinese aid and ethnic identities: Mechanisms}

The idea that Chinese development projects may fuel local ethnic identities rests on a constructivist account of ethnicity, according to which ethnic identities are mobilized in the pursuit of state resources as opposed to being primordial and hardwired (see e.g. Posner, 2003; Posner, 2004; Kasara, 2007; Eifert et al., 2010). ${ }^{1}$ Against this background, the study considers two (non-mutually exclusive) channels through which aid projects may fuel local ethnic identities.

First, competition for the inflow of resources that aid constitutes could mobilize ethnic identities across the board. The results of Eifert et al. (2010), mentioned above, speak in favour of such a mechanism. In particular, drawing on survey data across 10 African countries their findings suggest that ethnic cleavages are more salient at election times and in cases where the winning party won by a small margin. They interpret this as supporting an instrumental understanding of ethnicity, where ethnic identities are mobilized in the struggle for political power and economic resources. By this reasoning, the inflow of resources could fuel ethnic identities even in the absence of ethnic bias, simply by raising the stakes in the struggle for resources.

A second possible mechanism, however, is that perceived ethnic bias in the delivery of aid fuels ethnic grievances and identities in groups that perceive themselves as disadvantaged. The idea that unequal treatment of ethnic groups raise group members' ethnic awareness is in line with a 'reactive ethnicity' approach, according to which ethnic mobilization is prompted by an unequal division of resources along ethnic lines (Vermeersch, 2011). Studies in psychology and sociology have shown that systematic discrimination of ethnic minorities may result in

\footnotetext{
${ }^{1}$ There is also experimental evidence to this effect. Public goods games in Uganda demonstrate that the possibility of social sanctions influence whether individuals treat coethnics differently than members of other groups. In particular, co-ethnics are only more likely to favour each other if they are seen to do so, and thus risk that noncooperative behavuiour is met with future sanctions (Habyarimana et al., 2007, 2009).
} 
increased ethnic identification among the minorities' group members (see the discussion in Çelik, 2015). Considering the recent empirical evidence that Chinese development finance is particularly prone to elite capture and possible ethnic bias (Dreher et al., 2016), the discussion below will focus on potential sources of ethnic bias in the (Chinese) aid delivery process.

\subsection{Three levels of potential ethnic bias in the aid delivery process}

Ethnic bias could take place at different levels and take different forms depending on the type and targeting of the projects. In particular, it is useful to make a distinction between ethnic bias in 1) geographic allocation, 2) local implementation and 3) local rewards. Ethnic bias in geographic allocation implies that development projects (for whatever reason) tend to be located in areas disproportionately populated by particular ethnic groups. Ethnic bias in local implementation, on the other hand, refers to a situation where the local implementation process of development projects - e.g. in terms of staffing and contracts awarded - systematically benefits some particular group. Ethnic bias in local rewards, finally, refers to ethnic bias in the local distribution of the end product of the project.

Consider a development project focusing on building schools. Ethnic bias in geographic allocation would imply that the schools are built in areas disproportionately populated by a specific ethnic group. Ethnic bias in local implementation of the school project could for instance refer to a situation where building contracts awarded and teachers hired systematically benefit a particular group in the local areas. Ethnic bias in local rewards, finally, would in this particular example refer to kids from a particular group getting preferential access to the schools. Of course, the bias may well operate on more than one level.

Figure 1 illustrates the variety of forms the bias could take depending on which level(s) it operates. For instance, even if there is no ethnic bias in the geographic allocation stage - i.e. Chinese projects do not systematically favour regions disproportionately populated by a particular ethnic group - there may well be ethnic bias in the local implementation and distribution of rewards. Indeed, if there is ethnic bias in the local government and they are given substantial discretion during the implementation phase of the project, this seems likely.

The third stage - the local distribution of rewards - is closely related to the degree of excludability of the end product, which has implications for how narrowly the good can be targeted, and to what extent benefits are likely to spill over to different groups (see the reasoning in Isaksson and Bigsten, 2017). If the development project involves the distribution of public goods, then even if there is ethnic bias in geographic allocation, benefits are still 
likely to spill over to other groups. If, on the other hand, the rewards from a development project consist in narrowly targeted private (i.e. excludable) goods, then with ethnic bias in local rewards, benefits need not spill over to other groups. Rather, the patronage network may in effect be narrower than the ethnic group, meaning that many co-ethnics of the politician in power are still excluded from the rewards (Kasara, 2007).

\subsection{Chinese development finance and risk of ethnic bias}

Two related features of Chinese development finance give partner country governments considerable discretion in the distribution of funds, thereby arguably making it prone to elite capture and possible ethnic bias in geographic allocation and local implementation and distribution of rewards. First, China has an explicit policy of non-interference in the domestic affairs of recipients (State Council, 2014). While recipient country governments tend to see the principle as a sign of China respecting their countries' sovereignty, critics view it as a convenient rationale for economic involvement in undemocratic and corrupt regimes and suggest that it makes Chinese aid easy to exploit for politicians (see e.g. Tull, 2006; Kaplinsky et al., 2007; Naím, 2007; Pehnelt, 2007; Marantidou and Glosserman, 2015).

Second, and related, the demand-driven nature of the Chinese aid allocation process (see e.g. Brautigam, 2011) arguably gives the domestic authorities in partner countries leeway to allocate funds to activities and locations that best suit their own interests. As described in detail in Dreher et al. (2016), China's aid allocation tends to be based on requests from recipientcountry governments. Their aid packages and projects are often negotiated in high-level meetings with political leaders rather than publicly outlined in country development assistance strategies, with the initiative generally coming from the recipient side. Interpreted favorably, this could again be seen as a sign of ensuring partner country ownership of development policy. And importantly, African leaders may use the discretion in the distribution of Chinese funds to address key development challenges that have not attracted sufficient funding from Western donors. At the same time, however, a request-based system of aid project delivery may provide opportunities for recipient country governments to use funds strategically by promoting a subnational distribution of funds that favors their patronage network. As noted, there is both anecdotal reports and systematic empirical evidence (Dreher et al., 2016) suggesting that political leaders have used Chinese aid for political advantage or self-enrichment.

Furthermore, what should matter for agents' attitudes and behaviour is perceived rather than de-facto ethnic bias in aid delivery (see the discussion in Isaksson, 2011). Irrespective of 
de-facto ethnic bias, citizens may perceive their group as being disadvantaged and mobilize ethnic identities accordingly. Perceptions of ethnic bias should depend on to what extent the project is visible - meaning that local citizens are aware of its existence - and the degree to which it is interpreted as inclusive, i.e. as benefiting the general population rather than a select few, and ethnically neutral. Chinese development projects arguably stand out from the projects of Western donors on both accounts. Several scholars suggest that China tends to finance symbolic infrastructure projects and prestigious buildings such as presidential palaces, sports stadiums, government buildings and conference centers rather than more broad-based interventions (see e.g. Tull, 2006; Brautigam 2011a, Strange et al 2013).

\subsection{Empirical implications}

Against this background, it is interesting to study whether Chinese development projects fuel local ethnic identities, and whether the potential effect varies depending on whether the respondents belong to an in-group - proxied by being a co-ethnic with the country president at the time of the survey - or an out-group.

The existence (or lack) of parameter heterogeneity arguably sheds light on the theoretical mechanisms involved. If there is an effect, and it is uniform across groups, this would seem to imply that it is competition for the inflow of resources in and of itself, rather than perceptions of ethnic bias in the distribution of these resources, that mobilize ethnic identities. If the effect is significantly stronger in the out-group, on the other hand, this arguably signals that the effect is driven by ethnic grievances originating in perceived ethnic bias in disadvantaged groups.

Provided that ethnic bias in aid allocation and implementation is not a universal phenomenon existing across all donors, comparing the results for Chinese development projects with those obtained when considering the projects of other influential donors could also be revealing in this regard. If the hypothesized effect is observed for all donors, this too would arguably add support to the idea that it is competition for the inflow of resources more generally, rather than perceived ethnic bias in the distribution of these resources, that mobilize ethnic identities. The next section elaborates on how to address the research questions empirically.

\section{Data and empirical strategy}


To explore the local effects of Chinese development projects on ethnic identities in Africa, I geographically match spatial data on China's official financial flows to the continent over the period 2000-2014 with 94,954 respondents from 18 African countries ${ }^{2}$ obtained from rounds 3-6 of the Afrobarometer survey.

The data on Chinese aid projects is obtained from geo-referenced project-level data of AidData's Geocoded Global Chinese Official Finance Version 1.1.1 dataset (Bluhm et al., 2018). Since the Chinese government does not release official, project-level financial information about its foreign aid activities, this data is based on an open-source media based data collection technique, synthesizing and standardizing a large amount of information on Chinese development finance to African countries (described in detail in Strange et al., 2013 and 2015). While information extracted from public media outlets is of course an imperfect substitute for complete statistical data from official sources, the authors provide a careful description of how they dealt with challenges in the data collection process. ${ }^{3}$ Furthermore, the only information used here is whether, where and when a project was implemented. That is, I do not make use of potentially sensitive and less reliable information on e.g. specific aid volumes or details from the implementation process.

The aid data contains latitude and longitude project co-ordinates, and provide information about the precision of the location identified (for details about the geocoding methodology used, see AidData Research and Evaluation Unit, 2017). While some development projects are implemented in a limited geographical area, such as a village or city, others are realized at more aggregate levels, such as a district or greater administrative region. Hence, project locations are coded into different categories depending on the degree of precision of the specified location, ranging from category 1 for coordinates to an exact location, to 8 when the location is estimated to be a seat of an administrative division or the national capital (see Strandow et al. 2011). Being interested in local effects of Chinese development projects, I focus on projects with recorded locations coded as corresponding to an exact location or as 'near', in the 'area'

\footnotetext{
${ }^{2}$ The benchmark estimation sample is restricted to include the 18 Afrobarometer countries with observations connected to both ongoing and future Chinese development projects, i.e. the countries that have both a post- and a pre-treatment group of respondents (see Section 3.1). These are: Benin, Botswana, Botswana, Burundi, Cameroon, Cape Verde, Cote D'Ivoire, Ghana, Guinea, Kenya, Liberia, Madagascar, Malawi, Mali, Mauritius, Mozambique, Namibia, Niger, Nigeria, Senegal, Sierra Leone, South Africa, Tanzania, Togo, Uganda and Zimbabwe.

${ }^{3}$ See also Muchapondwa et al., 2014, for a validation using a 'ground-truthing' methodology.
} 
of, or up to $25 \mathrm{~km}$ away from an exact location (precision categories 1 and 2 in Strandow et al. 2011).

The point coordinates in the aid data are used to link aid projects to local survey respondents in the Afrobarometer. The coordinates of the surveyed Afrobarometer clusters, consisting of one or several geographically close villages or a neighborhood in an urban area, are used to match individuals to aid project sites with precise point coordinates. As in Isaksson and Kotsadam (2018a and 2018b), I measure the distance from the cluster centre points to the aid project sites and identify the clusters located within a cut-off distance - here $25 \mathrm{~km}$ - of at least one project site. Figure 2 maps the Chinese projects with precise geocodes and start-dates across the African continent, along with the Afrobarometer survey clusters encircled by $25 \mathrm{~km}$ buffer zones. The 18 countries in the benchmark estimation sample contain 276 such project sites. The estimation strategy, described further below, will rely on identifying survey respondents within $25 \mathrm{~km}$ of project sites, i.e. in clusters where an ongoing or future Chinese project lies within the $25 \mathrm{~km}$ buffer zone.

The dependent variable focuses on ethnic identification. To capture the salience of ethnic identities, I use a question asking whether the respondent identifies primarily with his or her ethnic group or with his or her country, creating a dummy variable indicating if the respondent reports to identify more in ethnic than in national terms. ${ }^{4}$ In the overall estimation sample, 13 percent of the respondents report to identify in ethnic terms (Table A1), the corresponding country shares ranging from around 4 percent in Tanzania and Cape Verde, to around 24 percent in Mali (Figure A1).

The main explanatory variables, which will be described in greater detail below, focus on living near a Chinese project site - either a site where a project is being implemented at the time of the survey (Ongoing) or a site where a project will be opened but where implementation had not yet been initiated at the time of the survey (Future).

To explore whether the potential effect of living close to a Chinese project site varies depending on the status of one's ethnic group, another key explanatory variable combines information on self-reported ethnic group affiliation ${ }^{5}$ with external data on the ethnic

\footnotetext{
${ }^{4}$ Based on the question "Let us suppose that you had to choose between being a [national ID] and being a [respondent's ethnic group]. Which of the following best expresses your feelings?" with the following response categories: 1=I feel only [Respondent's ethnic group], 2=I feel more [Respondent's ethnic group] than [national ID], 3=I feel equally [national ID] and [Respondent's ethnic group], 4=I feel more [national ID] than [Respondent's ethnic group] 5=I feel only [national ID], 7=Not applicable.

${ }^{5}$ Based on the question "What is your ethnic community, cultural group or tribe?".
} 
affiliations of heads of government in office. More specifically, I construct a dummy variable indicating whether the respondent belongs to the same ethnic group as the country's president at the time of the survey (In-group), and then interact this indicator with the variables for living close to Chinese project sites. Variable descriptions and summary statistics are presented in Tables A1-A2.

\subsection{Estimation strategy}

The distribution of aid within countries is by no means random, implying that some individuals and sub-national areas, with certain characteristics, will be more likely than others to be targeted by aid. Members of the same ethnic group often live geographically clustered and a common argument is that African policy-makers tend to favour their own homelands and ethnic groups in the allocation of funds. Hence, some areas and ethnic groups - and thus a non-random group of individuals with particular ethnic identities and living conditions - will presumably be more likely to be targeted by aid than others. For this reason, it is not plausible to assume that there is no relationship between project localization and the pre-existing characteristics of project sites and of the population residing in the surrounding areas. The implication is that it is problematic to draw conclusions about the causal effect of aid on ethnic identities from a direct comparison of the ethnic identities of people living close to and far away from project sites.

In order to deal with these empirical challenges, I use a spatial-temporal estimation strategy resembling that in Knutsen et al. (2016). ${ }^{6}$ In particular, I compare the estimated effect of living near sites where a Chinese development project is currently under implementation with the estimated effect of living near sites where a project will be opened but where implementation had not yet been initiated at the time the Afrobarometer covered that particular area.

While the fact that the Afrobarometer is not a panel hinders me from following specific localities over time, before and after a project was initiated, with this estimation strategy I can still make use of the time variation in the data. Specifically, I utilize the fact that there is information about at what point in time and in what localities aid projects have been implemented, and that the survey data covers different localities at different points in time. This makes it possible to identify respondents living in areas where a project was ongoing at

\footnotetext{
${ }^{6}$ See also Isaksson and Kotsadam (2018a and 2018b).
} 
the time of the survey and compare them with respondents living in areas where, in hindsight, we know that a project will start, but where implementation had yet to begin at the time of the survey.

Assuming that ethnic identities are affected within a cut-off distance of Chinese projects, the main identification strategy includes three groups of individuals, namely 1) those within 25 $\mathrm{km}$ of at least one ongoing project site (Ongoing, applying to 19 percent of respondents), 2) those within $25 \mathrm{~km}$ of a site where a project will start, but where implementation was yet to begin at the survey date and not close to any ongoing projects (Future, applying to 3 percent of respondents), and 3) those with more than $25 \mathrm{~km}$ from any project site (the omitted reference category in the regressions, applying to 78 percent of respondents). ${ }^{7}$ The baseline regression takes the form:

(1) $Y_{i v t}=\beta_{1} \cdot$ Ongoing $_{i t}+\beta_{2} \cdot$ Future $_{i t}+\alpha_{s}+\delta_{t}+\gamma \cdot \mathbf{X}_{i t}+\varepsilon_{i v t}$

where the ethnic identity $Y$ for an individual $i$ in cluster $v$ at year $t$ is regressed - in the benchmark setup using linear probability models - on a dummy variable Ongoing capturing whether the individual lives within the specified cut-off distance of an ongoing Chinese development project, and a dummy Future for living close to a site where a Chinese project is planned but not yet implemented at the time of the survey. To control for variation in average levels of ethnic identities across time and space, the regressions include country fixed effects $\left(\alpha_{s}\right)$ and year fixed effects $\left(\delta_{t}\right)$. To control for individual variation in ethnic identities, a vector $\left(\mathbf{X}_{i}\right)$ of individual-level controls from the Afrobarometer are included. The baseline set of individual controls are age, age squared, gender and urban/rural residence. To account for correlated errors, the standard errors are clustered at the geographical clusters (i.e., at the enumeration areas which correspond to either a village, a town or a neighborhood). In another set of regressions I add an interaction term between Ongoing and the variable indicating whether the respondent belongs to the same ethnic group as the country's president at the time of the survey (In-group).

Interpreting the coefficient on Ongoing $\left(\beta_{1}\right)$ in isolation as capturing an effect of Chinese development projects on local ethnic identities would necessitate that the location of Chinese development projects is not correlated with pre-existing ethnic sentiments. As can be

\footnotetext{
${ }^{7}$ I exclude respondents who live within the cut-off distance of a site where the implementation of a project has been completed prior to the interview date (4.6 percent of respondents, see Table A1).
} 
understood from the above discussion, this assumption is not judged as reasonable. Including Future enables me to compare sites with ongoing projects to other areas selected as locations for Chinese projects, but where the project was yet to be initiated at the time of the survey. My focus is thus on the parameter difference between Ongoing and Future (i.e. $\beta_{1}-\beta_{2}$, with associated test results), giving a difference-in-difference type of measure ${ }^{8}$ that controls for unobservable time-invariant characteristics that may influence selection into being a Chinese project site.

A potential concern would be if ongoing/future project status picks up project timing and projects starting later differ systematically from projects starting earlier. Here it is important to note that there is no direct correspondence between when a project was implemented and whether it is coded as Ongoing or Future; ongoing/future status depends on project status at the time the Afrobarometer survey covered the particular area in question. To illustrate, consider Figure A2. In this example, people living in area A, surveyed in 2005, are connected to a future project starting in 2007, and people living in area B, surveyed in 2011, are connected to an ongoing project that started in 2009. Hence, although the project in area B started two years later than the project in area A, it is still the project in area A that is classified as a future project, all depending on when the survey covered the areas in question.

Furthermore, this type of time variation - with some areas being surveyed earlier and others later - exist within as well as across survey waves. Considering the concern that projects implemented later may differ systematically from projects implemented earlier, this is reassuring. That said, however, there is an over-representation of respondents connected to ongoing projects in the later survey waves, why the possible effects of project timing will be evaluated in the sensitivity analysis.

Using the above approach to study whether Chinese development projects affect local ethnic identities, one has to make an assumption about the geographical reach of the potential effect. This, in turn, should reasonably depend on how far from project sites citizens are aware of the project's existence and its distribution of rewards. In particular, observing a project being implemented without experiencing any of its benefits could - if the perceived unfairness is interpreted in ethnic terms - presumably fuel ethnic grievances. As discussed in Knutsen et al.

\footnotetext{
${ }^{8}$ Comparing the difference between post-treatment individuals (with an ongoing Chinese project within $25 \mathrm{~km}$ ) and control individuals (with no Chinese project - ongoing or future - within $25 \mathrm{~km}$ ) with the difference between pre-treatment individuals (with a future Chinese project within $25 \mathrm{~km}$ ) and control individuals within the same country and year (due to country and year fixed effects).
} 
(2016), the appropriate cut-off distance from a project - within which an individual will be considered 'treated' - is an empirical question. I use a $25 \mathrm{~km}$ cut-off in the benchmark estimation, but results using alternative cut-offs (50 and $75 \mathrm{~km})$ are also presented.

\section{Results}

The benchmark results, presented in Column 1 of Table 1, indeed indicate that respondents living near an ongoing rather than a future project are more likely to identify in ethnic terms. The estimation demonstrates the importance of taking the non-random selection of Chinese project sites into account. Looking at the parameter of interest in isolation, the results at first sight seem to indicate that, if anything, people living close to an ongoing Chinese project are less likely to identify in ethnic terms. As noted, however, interpreting the parameter of the Ongoing variable as capturing an effect of Chinese development projects on ethnic identities requires that the location of Chinese development projects is not correlated with pre-existing ethnic sentiments in these areas.

As it turns out, the negative and statistically significant coefficient on future in Column 1 suggests that Chinese projects tend to be located in areas with lower pre-existing ethnic identification. If not accounting for this tendency one would thus underestimate the effect of the Chinese presence. The comparison of respondents living in areas with ongoing and future projects $\left(\beta_{\text {ongoing }}-\beta_{\text {future }}\right)$ and associated test results are presented in the bottom rows of Table 1. The results indicate that those with an ongoing rather than a future project in their vicinity are 2.3 percentage points more likely to identify in ethnic terms, statistically significant at the 5 percent level. In relation to the overall sample mean of the dependent variable (Table A1), the difference is 18 percent and thus quite sizeable.

\subsection{Sensitivity analysis}

A similar pattern is observable in a range of alternative specifications (Columns 2-12, Table 1). Using a wider geographic cut-off - $50 \mathrm{~km}$ rather than 25 (see Column 2) - the difference seemingly shrinks slightly but is still statistically significant. Considering an even wider radius around project sites $(75 \mathrm{~km}$, see Column 3$)$ the pattern is similar, but the difference ( $\beta_{\text {ongoing }}-$ $\left.\beta_{\text {future }}\right)$ is no longer statistically significant, thus suggesting that the effect fades with distance from project sites, as can be expected. Calculating the marginal effects from a probit estimation rather than using a LPM (Column 4), the observed difference remains positive but is not quite 
statistically significant. Using an ordinal variable (ranging from 1-5, increasing in ethnic identification) rather than a dummy as dependent (Column 5), thereby capturing the individual's degree of ethnic identification, does not change the interpretation of results.

The benchmark specification excludes respondents who live within the cut-off distance of a site where a Chinese project has been completed prior to the interview date (approximately 5 percent of respondents). The argument is that this, through various possible interaction effects, may otherwise bias the effect of having an ongoing project nearby, e.g. by inflating ethnic identities among supposedly untreated individuals or by interfering with the effect of (postand pre-) treated individuals living close to ongoing or future sites. The estimation in Column 6 , however, instead keeps these individuals in the regression, but includes a dummy variable to control for having a completed project within the cut-off distance. The statistically significant difference in ethnic identification between individuals living close to ongoing and future Chinese project sites remain (the parameter for having a completed project nearby is not statistically significant).

The benchmark estimation sample is restricted to include only the 18 Afrobarometer countries with observations connected to both ongoing and future Chinese development projects, i.e. the countries that have both a post- and a pre-treatment group of respondents. The estimation presented in Column 7 relaxes this restriction, and includes 8 additional countries that only have observations falling into either the post- or pre-treatment category. ${ }^{9}$ The benefit of this is, of course, that the estimated parameters of ongoing and future are based on a larger sample. The drawback is the limited common support, or overlap in terms of covariates, this is likely to give between respondents connected to ongoing and future Chinese development projects. In cases where both post- and pre-treatment groups are not present within the same country, one may argue that the conditions of the two groups are too different to allow for meaningful comparisons. Nevertheless, we can note that the results based on the larger sample are in line with the benchmark results for the more restricted sample.

The baseline estimations are based on Afrobarometer data geocoded with precision code 1-3 (see the discussion in Section 3). The estimation presented in Column 8 instead restricts the sample to include only observations geocoded with precision code 1 . While preferable in

\footnotetext{
${ }^{9}$ In principle, this means allowing in countries with post-treatment, but no pre-treatment, individuals, namely Burundi, Cameroon, Cote D'Ivoire, Guinea, Mauritius, Niger, Sierra Leone and Zambia. None of the sample countries have pre-treatment, but not post-treatment, individuals.
} 
terms of precision, considering that only 56 percent of the respondents fall into this category, this endeavour is arguably problematic in terms of representativeness. Nevertheless, we can note that while the estimated parameters of ongoing and future for this sample are of a similar magnitude compared to in previous estimations, they are not statistically different from each other.

The benchmark estimation considers all Chinese development projects (remaining after relevant sample restrictions) listed by AidData. As noted, however, China tends to mix commercial interests with concessional flows. In order to qualify as overseas development assistance (ODA), according to the OECD-DAC definition, an aid flow must be concessional, have a grant element of at least 25 percent, and its main objective should be the promotion of economic development of developing countries (OECD-DAC glossary, 2016). For comparability with Western donors, Column 9 restricts the sample of Chinese projects to include only those judged as 'ODA-like' by AidData coders (see Strange et al., 2015). The results are in line with the benchmark estimation.

As discussed in Section 3.1, a potential concern would be if ongoing/future project status picks up project timing and projects starting later differ systematically from projects starting earlier. Here it is important to note that there is no direct correspondence between time of project implementation and ongoing/future project status. A project implemented comparatively early may well be coded as a future project, all depending on at what point in time the Afrobarometer surveyed that particular area. Furthermore, it is reassuring that this type of time variation exist within as well as across Afrobarometer survey waves; all except the last individual survey waves contain observations connected to both ongoing and future Chinese project sites. That said, however, there is an over-representation of respondents connected to ongoing project sites in the later survey waves. And at the time of wave 6 , which interviewed respondents in 2014 and 2015, all Chinese projects included in the dataset had already been initiated, meaning that there are no respondents connected to future project sites in this round. Including wave 6 comes with the benefit of a significantly larger sample. However, to explore if the lack of pre-treatment observations in this survey round is what drives the results, the estimation in Column 10 excludes the observations from wave 6. The results remain qualitatively the same.

The variables ongoing and future simply indicate if a Chinese project is under implementation or will take place in the future in an area. They do not provide any information about project duration or of how far into the future the project will start. To limit the variation in project duration and time until project start, the estimation in Column 11 focuses only on 
projects that started (relevant for ongoing) or will start (relevant for future) within five years of the interview date. While making the pre- and post-treatment groups smaller, this arguably makes them more comparable, limiting the amount of possible changes taking place in the areas between the interview date and the implementation date. Again, the key result remains unchanged.

Another concern would be potential pre-start effects. If the local population receives information about a Chinese project ahead of the project implementation period, this could presumably fuel ethnic identities prior to project start. If so, the difference between the Ongoing and Future parameters would underestimate the effect of the Chinese project on ethnic identities. Considering the lack of transparency concerning Chinese development projects such anticipation effects would reasonably mainly concern projects starting in the relatively near future. To explore whether pre-start effects influence the results, Column 12 excludes observations connected to future projects starting within the next year. The estimated difference between the Ongoing and Future parameters indeed becomes larger (3.3 percentage points compared to 2.3 in the benchmark estimation), seemingly indicating that the effect on ethnic identities is to some extent triggered in the immediate period ahead of project implementation. Considering the results of Eifert et al. (2010), suggesting stronger ethnic identification as elections draw nearer, this is reasonable.

In the benchmark setup, country and year fixed effects control for variation in average levels of ethnic identities across time and space. However, time trends in ethnic identification may well vary across countries, for instance due to where in their electoral cycles the respective countries are at the time of the different survey rounds (again, in line with the results of Eifert et al., 2010). Column 13, allows for country specific time trends. ${ }^{10}$ Reassuringly, the results are in line with in the benchmark setup.

\subsection{Heterogeneity across in-group and out-group}

Above we considered the local effect of Chinese development projects on the ethnic identities of citizens in general, making no distinction between people from different ethnic groups. Arguably, though, these potential effects are unlikely to be uniform across groups. If the allocation and implementation of Chinese development projects involve ethnic bias, from which co-ethnics of the country's president stand to gain, one may suspect ethnic grievances,

\footnotetext{
10 Interacting the full set of country dummies with the full set of year dummies.
} 
arguably fueling ethnic identities, among people belonging to other groups that perhaps do not benefit to the same extent. This section assesses whether the effect of living near a Chinese development project varies across in-group and out-groups, defined in terms of co-ethnicity with the country's top leadership.

In a first step, let us explore whether in-groups and out-groups differ systematically in terms of geographic proximity to Chinese development projects. Using the terminology from Section 2, is there ethnic bias in geographic allocation of Chinese projects? Dreher et al. (2016) found little evidence of ethnic bias in Chinese aid at the regional level, based on estimations focusing on ethnographic regions defined in the Geo-referencing of Ethnic Groups (GREG) data project of Weidmann et al, (2010). Here we consider project exposure at a more local level, running individual level regressions relating proximity to Chinese development project sites to self-reported ethnic group affiliations.

The results, presented in Table 2, provide some indication that in-groups and out-groups differ in terms of geographic proximity to Chinese project sites. Conditional on baseline controls, year- and country fixed effects, co-ethnics of the country president are 1.2 percentage points more likely than members of other groups to live near a site where a Chinese project will be implemented in the future. Moreover, they tend to have a greater number of Chinese projects within $25 \mathrm{~km}$. Based on the data at hand, we cannot judge whether this pattern is purposeful - it may well be driven by, say, better infrastructure or economic opportunities in areas where the in-group is over-represented rather than an intention to favour or discriminate certain groups. Moreover, the observed differences are relatively small, and in terms of the probability of having an ongoing Chinese projects within $25 \mathrm{~km}$ and with regard to the distance to nearest Chinese project, co-ethnics of the president do not stand out from members of other groups.

Importantly, however, measures of geographic proximity to Chinese projects do not capture ethnic bias in local implementation and rewards, or perceptions thereof. It may be that Chinese projects disproportionately cater to the needs of the in-group. In effect, regardless of whether this is true, members of other ethnic groups may perceive that they are excluded from the rewards, which may fuel ethnic grievances. Lacking a direct measure of ethnic bias in local implementation and rewards of Chinese development projects, what one can do, is consider whether the Chinese presence has different effects on the ethnic identities of in-groups and outgroups in the local area.

The estimations in Table 3 include the dummy variable for belonging to the in-group. In Column 1, we can note that compared to people from other groups, co-ethnics of the president 
are around 2 percentage points less likely to identify in ethnic terms, conditional on baseline controls. If ethnic grievances fuel ethnic identities, lower ethnic identification in a potentially privileged in-group is arguably not surprising. Another interpretation, in line with some recent empirical evidence (Green, 2018), is that people are more likely to identify with the broader nation-state when a co-ethnic controls the state. The higher ethnic identification among people living close to ongoing as compared to future Chinese project sites remains intact.

Considering the possibility of perceptions of unfair treatment arising after project start, Column 2 introduces an interaction term between the dummy for belonging to the same group as the country president and the dummy for living close to ongoing Chinese development projects. This allows the effect of living near a Chinese project to vary depending on whether the respondent belongs to the in- or out-group. We see that for people not part of the president's ethnic group (in-group $=0$ ), living near an ongoing as compared to a future Chinese project site still comes with a greater tendency to identify in ethnic terms. For members of the in-group, on the other hand, this difference is not statistically significant. As discussed in Section 2, this finding is in line with the idea that the greater ethnic identification reported among people living close to ongoing (as compared to future) Chinese development projects could be driven by ethnic grievances originating in perceived ethnic bias.

\subsection{Heterogeneity across sub-samples}

The aggregate effect is likely to mask considerable variation across sample countries. The African countries in the sample differ considerably, not least with respect to the existence, nature and salience of ethnic divisions. The estimations presented in Table 4 explore heterogeneity across sub-samples. As it turns out, the estimated effect is by no means uniform across different samples.

To begin with, one may not expect the observed pattern in countries where ethnic identities are not salient. Splitting the 18 sample countries by the average share identifying in ethnic terms (Columns 1-2), we can in line with this note that the identified difference in ethnic identification between people living near ongoing and future Chinese project sites is only present in the nine country-sample where ethnic identities are more common.

Similarly, believing that perceptions of ethnic bias contribute to fueling ethnic identities near project sites, one may suspect the observed pattern to be more pronounced in countries marked by ethnic inequalities. As discussed by Alesina et al. (2016), ethnic inequality is likely to generate envy and perceptions that the system is unfair. The estimations in Columns 3 and 
4 split the sample countries by extent of ethnic inequalities, as measured by Alesina et al. (2016). ${ }^{11}$ The observed difference in ethnic identification is statistically significant in the high ethnic inequality sample, but not quite so in the low inequality sample.

Furthermore, based on a modernization argument (see e.g. the discussion in Posner, 2004), one may suspect ethnic divisions to be more salient (and ethnically biased project implementation to be more visible?) in more traditional rural communities than in more dynamic urban areas. Whereas rural African communities are often suggested to be tightly knit, with ethnic and kinship relations regulating access to resources, urban dwellers are often assumed to be more individualistic (see the reasoning in e.g. Miguel and Gugerty, 2005). In line with this, the results in Columns 5-6 indicate that the observed difference in ethnic identification between people living near ongoing and future Chinese project sites is only present in the rural sub-sample.

By a similar modernization argument (but focusing on country- rather than urban-rural variation), one could argue that populations with better access to the internet and its flow of information are less likely to identify in traditional, local and ethnic terms (see e.g. the discussion in Kunst, 2014). The estimations in Columns 7-8 split the sample countries by their degree of internet penetration (International Telecommunications Union, 2018). The observed difference in ethnic identification near Chinese project sites is indeed only present in the low internet penetration sub-sample.

These sample splits are of course merely speculative. With only 18 sample countries, we cannot draw any broader conclusions on systematic country variation in results. The results do, however, serve as a reminder that the observed pattern is an average effect, and not uniform across sample countries.

\subsection{Comparison with other donors}

Chinese development projects seemingly stand out from other influential donors in terms of fueling ethnic identities. Replicating the key regressions for World Bank projects (Table 5), ${ }^{12}$

\footnotetext{
${ }^{11}$ Constructed by comparing night-time light across homelands of ethnolinguistic groups (obtained from the GeoReferencing of Ethnic Groups (GREG) database).

${ }^{12}$ Using data from AidData (World Bank IBRD-IDA, Level 1, Version 1.4.1), covering all World Bank projects approved between 1995 and 2014. Again, the sample is limited to include only projects with precise geocodes and information about start year, resulting in 688 World Bank projects spread across 6,663 project locations.
} 
for which there is also geo-referenced data available for a large multi-country African sample, the results do not suggest an equivalent pattern. In fact, they indicate the reverse, i.e. that living near an ongoing as opposed to a future project comes with weaker ethnic identification. ${ }^{13}$ Moreover, this effect is uniform across in- and out-group, thus providing no indication of differential experiences across ethnic groups. A generous interpretation of the weaker ethnic identification observed near ongoing World Bank project sites is that ethnically neutral project implementation may act to attenuate ethnic identities in these areas. However, a more thorough analysis of World Bank projects would clearly be necessary in order to uncover the potential mechanisms involved. For the purpose of this study, it suffices to note that Chinese development projects stand out from World Bank projects in terms of fueling ethnic identities close to project sites.

Do the different results obtained for Chinese and World Bank projects simply reflect differences in the impact of bilateral and multilateral aid? Indeed, a common argument is that bilateral aid is often tied to the political agenda of the donor country and that it is less focused on promoting good governance in the recipient country (see the discussion in Charron, 2011). It is thus a good idea to compare the effects of Chinese aid projects to those of other bilateral donors.

For other bilateral donors, geocoded aid project data is available on a large scale only for a small selection of African countries. In particular, for Malawi, Nigeria, Uganda and Senegal there is geocoded aid data for both China and other donor countries, thus allowing for comparison. ${ }^{14}$ Table 6 presents the results of the equivalent regressions for other bilateral donor projects in these countries.

Again, the findings suggest a pattern different from that observed for Chinese projects. Just as for World Bank projects, the results for other bilateral aid, if anything, indicate that living near an ongoing as opposed to a future project comes with weaker ethnic identification. Moreover, there is again no indication of parameter heterogeneity across in- and out-group, and hence no suggestion of differential experiences across ethnic groups. While these results

\footnotetext{
${ }^{13}$ Restricting the estimation sample to include only countries with observations connected to both ongoing and future World Bank development projects results in a sample consisting of 13 of the 18 countries included in the benchmark sample for Chinese projects. For comparability, we can note that the benchmark result for Chinese projects remains when using this smaller sample. Furthermore, the World Bank result is stable over a wide range of specifications (equivalent to those presented in Table 1).

14 The benchmark result for Chinese projects remains when using this restricted sample.
} 
are not very robust across alternative specifications (not presented), probably reflecting the limited number of sample countries in focus and the heterogeneity of the donors included, they never indicate that having an ongoing project in the local area fuels ethnic identities. In sum, we can thus note that Chinese development projects seemingly stand out from other influential donors in this respect.

\section{Conclusions}

Recent empirical evidence suggest that Chinese aid may be particularly easy to exploit for politicians who are engaged in patronage politics. This raises important questions regarding potential externalities of aid. In particular, if development finance ends up in the pockets of political elites and their ethno-regional networks, does this exacerbate ethnic grievances and contribute to ethnic mobilization? The present paper examined whether Chinese development projects fuel local ethnic identities in African partner countries.

Two mechanisms through which this may occur were proposed. First, competition for the inflow of resources that aid constitutes could mobilize ethnic identities across the board. Second, perceptions of ethnically biased aid may fuel ethnic identities in disadvantaged groups. Against this background, the study asked whether the implementation of Chinese development projects fuels ethnic identities near project sites, whether the potential effect is uniform across groups, and whether it varies across donors.

The empirical analysis drew on a new geo-referenced dataset on the subnational allocation of Chinese development finance projects to Africa over the 2000-2014 period, geographically matched with 94,954 survey respondents across 18 African countries. To account for the endogenous placement of Chinese project sites, focus was on comparing the estimated effect of living near a site where a Chinese project was under implementation at the time of the interview, to that of living near a site where a Chinese project will appear after the interview date.

The empirical results indicate substantial country variation, serving as a reminder that the African countries in the sample differ considerably in terms of (for instance) the existence, nature and salience of ethnic divisions. On average, however, they indeed suggest that living near an ongoing Chinese project fuels ethnic identities, thus calling attention to a potentially important externality of aid. 
Notably, the effect is driven by people who belong to the out-group, i.e. those who are not co-ethnics of the country president at the time of the survey. The parameter heterogeneity arguably sheds light on the theoretical mechanisms involved; the fact that the effect is only present in the out-group may signal that it is driven by ethnic grievances originating in perceived ethnic bias rather than ethnic competition for resources more generally. The results indeed provide some indication, albeit modest, that members of the in-group are more likely to have a (future) Chinese project site in their vicinity. There is thus suggestive evidence of ethnic bias in geographic allocation in the sense that Chinese development projects, for whatever reason, tend to be located in areas disproportionately populated by the in-group. While we have no direct measure of ethnic bias in local implementation and rewards of Chinese development projects, the fact that Chinese projects only fuel local ethnic identities among members of the out-group may signal perceptions of ethnic bias.

Furthermore, if ethnic identities were mobilized by competition for the inflow of resources more broadly, rather than perceived ethnic bias in the distribution of these resources, one would arguably expect to observe a similar effect across all donors. As it turns out, however, Chinese development projects stand out from other influential donors in terms of fueling ethnic identities. Hence, this too seemingly speaks against the general ethnic competition mechanism.

Replicating the key analysis for World Bank projects as well as for other bilateral donors, the results in fact indicate the reverse, i.e. that living near an ongoing as opposed to a future project comes with weaker ethnic identification. Moreover, this effect is uniform across in- and out-group, thus providing no indication of differential experiences across ethnic groups. While a more thorough analysis would be necessary in order to verify these encouraging results across a wide range of donors, the suggestive evidence presented here opens for interesting future research: can aid projects, if implemented in an ethnically neutral fashion, in effect act to bring people together, across ethnic group lines?

The results call attention to the importance of considering the distributional consequences of aid, and of taking into account between group inequalities when doing so. Since ethnic bias could operate at several levels - in geographic allocation, during local implementation and in the local distribution of rewards - this requires an awareness of distributional impacts throughout the project implementation phase. On a more general level, the paper highlights the need to consider not only to what extent aid achieves its explicit objectives, but also its potential unintended effects, or externalities. These could be positive or negative and are likely to influence the long-term sustainability of a project. 


\section{References}

Ahlerup, P. and A. Isaksson (2015) "Ethno-regional favouritism in Sub-Saharan Africa", Kyklos, 68(2), pp. 143-152.

Akerlof, G. A. and R. E. Kranton (2000) "Economics and Identity", The Quarterly Journal of Economics, 115(3), pp. 715-753.

Alesina, A., Michalopoulos, S. and E. Papaioannou (2016) "Ethnic inequality", Journal of Political Economy, 124(2), pp. 428-488.

AidData Research and Evaluation Unit (2017) "Geocoding Methodology", Version 2.0. Williamsburg, VA: AidData at William \& Mary. https://www.aiddata.org/publications/geocoding-methodology-version-2-0.

Berlin, M. P., Bonnier, E. and A. Olofsgård (2017) "The donor footprint and gender gaps", mimeo, SITE Stockholm School of Economics.

Bluhm, R., Dreher, A., Fuchs, A., Parks, B., Strange, A. and M. Tierney (2018) "Connective Financing: Chinese Infrastructure Projects and the Diffusion of Economic Activity in Developing Countries”. AidData Working Paper \#64. Williamsburg, VA: AidData at William \& Mary.

Brautigam, D. (2009) The Dragon's Gift: The Real Story of China in Africa, Oxford, UK: Oxford University Press.

Bräutigam, D. (2011a) “Aid 'with Chinese characteristics': Chinese foreign aid and development finance meet the oecd-dac aid regime", Journal of International Development, vol. 23, pp. 752-764.

Brautigam, D. (2011b) “China in Africa: What Can the Western Donors Learn?”, Norwegian Investment Fund for Developing Countries (Norfund), August 2011.

Brazys, S., Elkink, J. A. and G. Kelly (2017) "Bad neighbors? How co-located Chinese and World Bank development projects impact local corruption in Tanzania", The Review of International Organizations, 12(2), pp 227-253. 
Briggs, R. C. (2014) “Aiding and Abetting: Project Aid and Ethnic Politics in Kenya" World Development, vol. 64, pp. 194-205.

Briggs, R. C (2017) “Does Foreign Aid Target the Poorest?”, International Organization, vol. 71, Winter 2017, pp. 187-206.

Brown, G., Stewart, F. and A. Langer (2010) "The implications of horizontal inequality for aid", In: Mavrotas, G., ed. Foreign Aid for Development: Issues, Challenges, and the New Agenda. Oxford: Oxford University Press, pp. 94-120.

Burgess, R., Jedwab, R., Miguel, E., Morjaria, A. and G. Padró i Miquel (2015). "The Value of Democracy: Evidence from Road Building in Kenya", American Economic Review, vol. 105(6), pp. 1817-51.

Çetin Çelik (2015) 'Having a German passport will not make me German': reactive ethnicity and oppositional identity among disadvantaged male Turkish second-generation youth in Germany, Ethnic and Racial Studies, 38:9, 1646-1662

Charron, N. (2011) "Exploring the impact of foreign aid on corruption: Has the "anti-corruption movement" been effective?", The Developing Economies, 49(1), pp. 66-88.

Clemens, M. A., Radelet, S., Bhavnani, R. R. and S. Bazzi (2012) "Counting Chickens when they Hatch: Timing and the Effects of Aid on Growth", The Economic Journal, 122(561), pp. 590-617.

Dreher, A., Nunnenkamp, P., \& Thiele, R. (2011). Are 'new'donors different? Comparing the allocation of bilateral aid between nonDAC and DAC donor countries. World Development, 39(11), 1950-1968.

Dreher, A., Fuchs, A., Parks, B., Strange, A. M. and M. J. Tierney (2015) “Apples and Dragon Fruits: The Determinants of Aid and Other Forms of State Financing from China to Africa", Working Paper 15, October 2015, Aid Data.

Dreher, A., Fuchs, A., Hodler, R., Parks, B. C., Raschky, P. A., and M. J. Tierney (2016) “Aid on demand: African leaders and the geography of China's foreign assistance", mimeo.

Eifert, B., Miguel, E. and D. N. Posner (2010) "Political competition and ethnic identification in Africa”, American Journal of Political Science, 54(2), pp. 494-510. 
Franck, R. and I. Rainer (2012) "Does the Leader's Ethnicity Matter? Ethnic Favoritism, Education, and Health in Sub-Saharan Africa", American Political Science Review, 106(2), pp 294-325.

Green, E. (2018) "Ethnicity, National Identity and the State: Evidence from Sub-Saharan Africa, British Journal of Political Science, pp. 1-23, doi:10.1017/S0007123417000783.

Habyarimana, J., Humphreys, M., Posner, D. and J. M. Weinstein (2007) "Why Does Ethnic Diversity Undermine Public Goods Provision?", American Political Science Review, 101(4), pp. 709-725.

Habyarimana, J., Humphreys, M., Posner, D. and J. M. Weinstein (2009) "Coethnicity: Diversity and the Dilemmas of Collective Action. New York: Russell Sage.

Hodler, Roland and Paul A. Raschky (2014). Regional Favoritism, Quarterly Journal of Economics. 129(2): 995-1033.

Hodzi, O. (2017) "China and Africa: economic growth and a non-transformative political elite", Journal of Contemporary African Studies, vol 9, pp. 1-16.

International Telecommunications Union (2018) "Percentage of Individuals using the Internet 2000-2017", International Telecommunications Union (Geneva), December 2018, available at: https://www.itu.int/en/ITU-D/Statistics/Pages/stat/default.aspx. accessed February 2019.

Isaksson, A. (2011) "Social divisions and institutions: assessing institutional parameter variation", Public Choice, 147(3), pp. 331-357,

Isaksson, A. (2017) "Geospatial analysis of aid: A new approach to aid evaluation", EBA (Expertgruppen för biståndsanalys) report 2017:09.

Isaksson, A. and A. Bigsten (2017) "Clientelism and ethnic divisions", African Affairs, 116(465), pp. 621-647.

Isaksson, A. and A. Kotsadam (2018a) "Chinese aid and local corruption", Journal of Public Economics, vol. 159, pp. 146-159.

Isaksson, A. and A. Kotsadam (2018b) "Racing to the bottom? Chinese development projects and trade union involvement in Africa”, World Development, vol. 106, pp. 284-298.

Jablonski, R. S. (2014) “How Aid Targets Votes: The Impact of Electoral Incentives on Foreign Aid Distribution”, World Politics, 66(2), pp. 293-330. 
Kaplinsky, R., McCormick, D. and M. Morris (2007) “The Impact of China on Sub-Saharan Africa”, IDS Working Paper no. 291, Institute of Development Studies at the University of Sussex Brighton.

Kasara, K. (2007) "Tax me if you can: Ethnic geography, democracy and the taxation of agriculture in Africa", American political science review. 101(1), pp. 159-172.

Kramon, E. and D. N. Posner (2016) "Ethnic Favoritism in Education in Kenya", Quarterly Journal of Political Science, 11(1), pp. 1-58.

Kunst, M. (2014) "The Link between ICT4D and Modernization Theory", Global Media Journal, 4 (2), pp. 1-22.

Lemarchand, R. (1972) "Political clientelism and ethnicity in tropical Africa: Competing solidarities in nation-building", The American Political Science Review, 66(1), pp. 68-90.

Lindberg, S. I. and M. K. C. Morrison (2008) “Are African voters really ethnic or clientelistic? Survey evidence from Ghana”, Political Science Quarterly, 123(1), pp. 95-122.

Marantidou, V. and B. Glosserman (2015) "China's double standard? Fighting corruption at home, turning a blind eye abroad", PacNet no. 13, Pacific Forum, Center for Strategic and International Studies (CSIS), Honolulu, February 2015.

Miguel, E. and M. K. Gugerty (2005) "Ethnic diversity, social sanctions, and public goods in Kenya", Journal of Public Economics, vol. 89, pp. 2325-2368.

Naím, M (2007) “Rogue Aid”, Foreign Policy, No. 159, March/April 2007.

Pehnelt, G. (2007) “The Political Economy of China’s Aid Policy in Africa”, Jena Economic Research Papers no. 051. University of Jena, Germany.

Powell, J. and M. G. Findley (2012) “The Swarm Principle? A Sub-national Spatial Analysis of Donor Coordination in Sub-Saharan Africa”, mimeo, may 172012.

Posner, D. (2003) “The Colonial Origins of Ethnic Cleavages: The Case of Linguistic Divisions in Zambia", Comparative Politics, 35(2) pp. 127-146.

Posner, D. N. (2004) “The political salience of cultural difference: Why Chewas and Tumbukas are allies in Zambia and adversaries in Malawi”, American Political Science Review, 98(4), pp. 529-545. 
Stewart, F., Brown, G. and L. Mancini (2005) "Why Horizontal Inequalities Matter: Some Implications for Measurement”, CRISE working paper no. 19, Centre for Research on Inequality, Human Security and Ethnicity, University of Oxford, June 2005.

Strange, A. M., Parks, B. C., Tierney, M. J., Fuchs, A., Dreher, A. and V. Ramachandran (2013) “China's Development Finance to Africa: A Media-Based Approach to Data Collection" CGD Working Paper 323. Washington, DC: Center for Global Development. Strange, A. M., Parks, B., Tierney, M. J., Fuchs, A. and A. Dreher, (2015), “Tracking underreported financial flows: China's development finance and the aid-conflict nexus revisited", Journal of Conflict Resolution, pp. 1-29.

The Economist (2017) "Chinese aid in Africa: No place like home", The Economist, No 57 , October 7, 2017.

The New York Times (2009) "China Helps the Powerful in Namibia”, S. LaFraniere, The New York Times, November 19, 2009.

Tull, D. M. (2006) “China’s Engagement in Africa: Scope, Significance and Consequences”, Journal of Modern African Studies, 44(3), pp. 459-479.

Wantchekon, L. (2003) "Clientelism and voting behaviour: Evidence from a field experiment in Benin”, World Politics, 55(3), pp. 399-422.

Vermeersch, P. (2011) “Theories of ethnic mobilization: Overview and recent trends", CRPD Working Paper No. 3 September 2011, Centre for Research on Peace and Development (CRPD) University of Leuven.

Öhler, H. and P. Nunnenkamp (2014) “Needs-Based Targeting or Favoritism? The Regional Allocation of Multilateral Aid within Recipient Countries”, Kyklos, 67(3), pp. 420-446 


\section{Figures and tables}

Figure 1: Three levels of ethnic bias in the aid delivery process

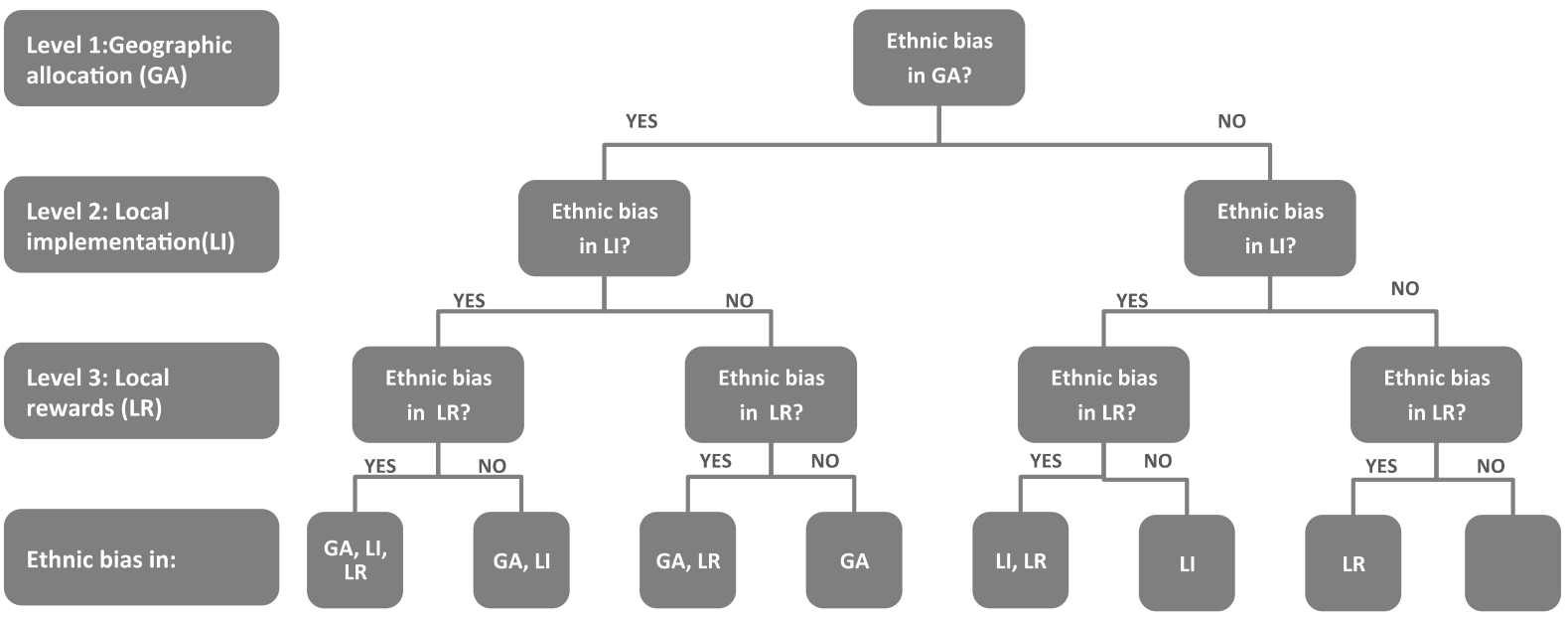




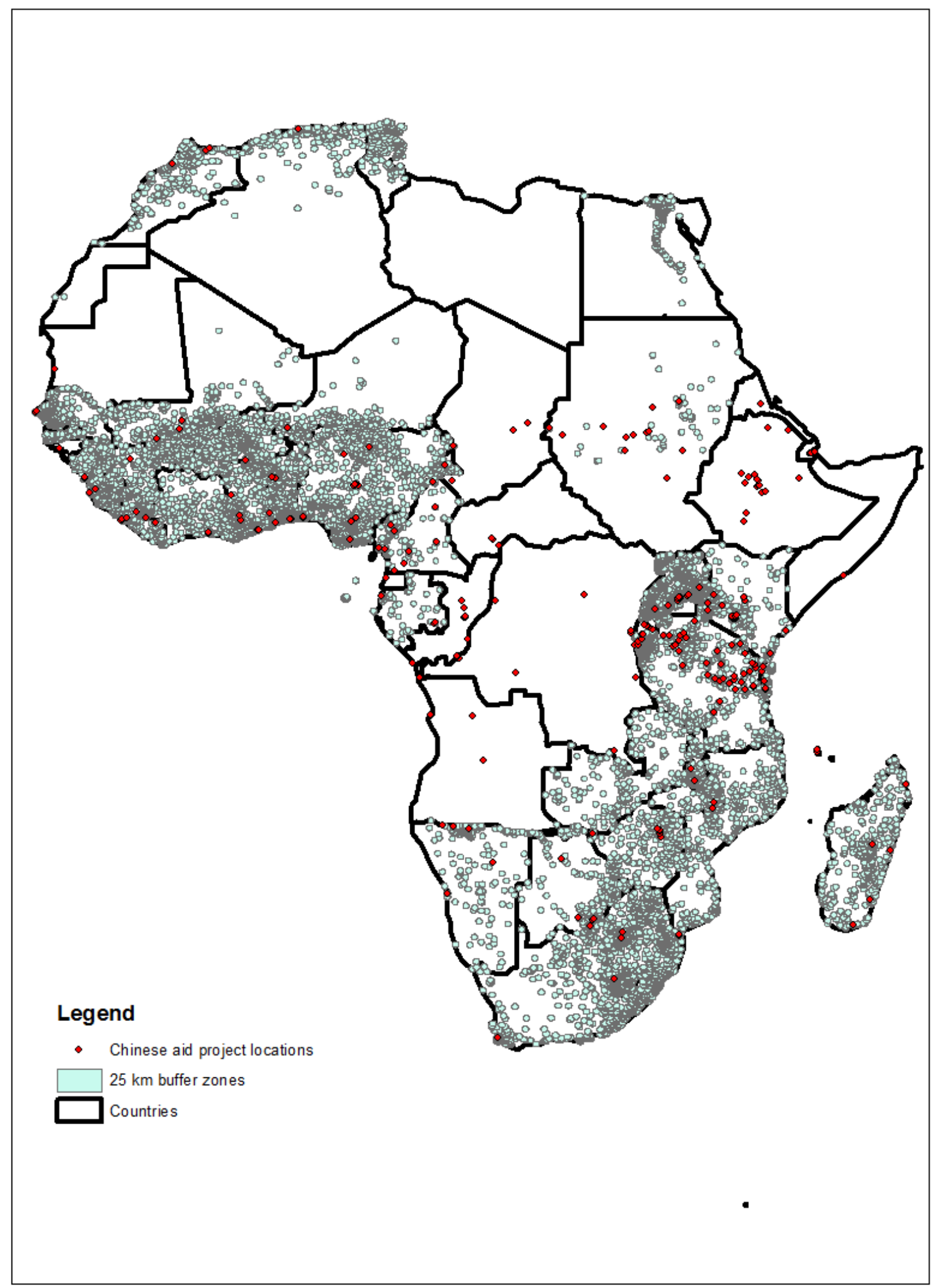


Table 1: Chinese aid and local ethnic identification

\begin{tabular}{|c|c|c|c|c|c|c|c|c|c|c|c|c|c|}
\hline VARIABLES & $\begin{array}{l}1) \\
25 \mathrm{~km} \\
\text { cutoff }\end{array}$ & $\begin{array}{l}(2) \\
50 \mathrm{~km} \\
\text { cutoff }\end{array}$ & $\begin{array}{l}3) \\
75 \mathrm{~km} \\
\text { cutoff }\end{array}$ & $\begin{array}{l}4) \\
\text { Probit }\end{array}$ & $\begin{array}{l}5) \\
\text { Ordinal } \\
\text { dependent }\end{array}$ & $\begin{array}{l}6) \\
\text { Including } \\
\text { completed }\end{array}$ & $\begin{array}{l}\text { (7) } \\
\text { Larger } \\
\text { estimation } \\
\text { sample }\end{array}$ & $\begin{array}{l}(8) \\
\text { Precision } \\
\text { code } 1\end{array}$ & $\begin{array}{l}\text { (9) } \\
\text { only ODA }\end{array}$ & $\begin{array}{l}(10) \\
\text { Without } \\
\text { wave } 6\end{array}$ & $\begin{array}{l}(11) \\
\text { Within } 5 \\
\text { years }\end{array}$ & $\begin{array}{l}\text { (12) } \\
\text { Excluding } \\
\text { next year } \\
\text { Future }\end{array}$ & $\begin{array}{l}(13) \\
\text { Country } \\
\text { specific } \\
\text { time } \\
\text { trends } \\
\end{array}$ \\
\hline Ongoing & $\begin{array}{l}-0.008^{*} \\
(0.005)\end{array}$ & & & $\begin{array}{l}-0.010^{*} \\
(0.005)\end{array}$ & $\begin{array}{l}-0.064^{* *} \\
(0.025)\end{array}$ & $\begin{array}{l}-0.009^{*} \\
(0.005)\end{array}$ & $\begin{array}{l}-0.008^{*} \\
(0.004)\end{array}$ & $\begin{array}{l}-0.012^{* *} \\
(0.005)\end{array}$ & $\begin{array}{l}-0.009^{*} \\
(0.005)\end{array}$ & $\begin{array}{l}-0.012^{* * *} \\
(0.005)\end{array}$ & $\begin{array}{l}-0.004 \\
(0.006)\end{array}$ & $\begin{array}{l}-0.008 \\
(0.005)\end{array}$ & $\begin{array}{l}-0.012^{* *} \\
(.005)\end{array}$ \\
\hline Future & $\begin{array}{l}-0.032^{* * *} \\
(0.011)\end{array}$ & & & $\begin{array}{l}-0.025^{* * *} \\
(0.010)\end{array}$ & $\begin{array}{l}-0.177^{* * *} \\
(0.057)\end{array}$ & $\begin{array}{l}-0.032^{* * *} \\
(0.011)\end{array}$ & $\begin{array}{l}-0.030^{* * *} \\
(0.011)\end{array}$ & $\begin{array}{l}-0.024^{* *} \\
(0.011)\end{array}$ & $\begin{array}{l}-0.032^{* * *} \\
(0.011)\end{array}$ & $\begin{array}{l}-0.031^{* * *} \\
(0.011)\end{array}$ & $\begin{array}{l}-0.030^{* * *} \\
(0.012)\end{array}$ & $\begin{array}{l}-0.041 \\
(0.013)\end{array}$ & $\begin{array}{l}-0.031^{* * *} \\
(0.011)\end{array}$ \\
\hline Ongoing & & $\begin{array}{l}-0.012 * * * \\
(0.004)\end{array}$ & & & & & & & & & & & \\
\hline Future & & $\begin{array}{l}-0.030^{* * *} \\
(0.008)\end{array}$ & & & & & & & & & & & \\
\hline Ongoing & & & $\begin{array}{l}-0.012^{* * *} \\
(0.004)\end{array}$ & & & & & & & & & & \\
\hline Future & & & $\begin{array}{l}-0.021^{* * *} \\
(0.008)\end{array}$ & & & & & & & & & & \\
\hline Diff ongoing-future & 0.0234 & 0.0187 & 0.00886 & 0.0800 & 0.113 & 0.0233 & 0.0214 & 0.0123 & 0.0226 & 0.0189 & 0.0268 & 0.033 & 0.019 \\
\hline $\begin{array}{l}\text { F test: ongoing- } \\
\text { future }=0\end{array}$ & 5.086 & 5.228 & 1.327 & 2.47 & 3.838 & 5.024 & 4.234 & 1.176 & 4.548 & 2.892 & 4.599 & 7.43 & 3.16 \\
\hline$p$ value of $F$ test & 0.0242 & 0.0223 & 0.249 & 0.1159 & 0.0501 & 0.0250 & 0.0397 & 0.278 & 0.0330 & 0.0891 & 0.0320 & 0.006 & 0.0757 \\
\hline Observations & 90,626 & 86,541 & 85,016 & 90,626 & 86,962 & 94,954 & 107,876 & 55,546 & 91,612 & 65,282 & 90,626 & 89,749 & 90,626 \\
\hline R-squared & 0.029 & 0.029 & 0.029 & & 0.074 & 0.029 & 0.029 & 0.029 & 0.029 & 0.035 & 0.029 & 0.0294 & 0.037 \\
\hline
\end{tabular}

Robust standard errors (clustered by the survey clusters) in parentheses; ${ }^{* * *} \mathrm{p}<0.01,{ }^{* *} \mathrm{p}<0.05,{ }^{*} \mathrm{p}<0.1$; All regressions include baseline controls and year and country fixed effects; Column 3 presents marginal effects frome the concerned coefficients, and the test-statistic and associated p-value to a chi2 distribution; In Column 10, ongoing25 and future25 include only projects that started or will start within 5 years of the interview date; Column 12 excludes the observations connected to future projects starting within the next year; Column 13 interacts the full set of country dummies with the full set of year dummies. 
Table 2: Chinese project localization: ethnic bias in geographic allocation?

\begin{tabular}{lcccc}
\hline VARIABLES & $\begin{array}{c}(1) \\
\text { Ongoing project } \\
\text { within 25 km }\end{array}$ & $\begin{array}{c}(2) \\
\text { Future project } \\
\text { within 25 km }\end{array}$ & $\begin{array}{c}\text { Number of projects } \\
\text { within 25 km }\end{array}$ & $\begin{array}{c}\text { (4) } \\
\text { Distance to nearest } \\
\text { project }\end{array}$ \\
\hline In-group & 0.009 & $0.012^{* *}$ & $0.213^{* *}$ \\
& $(0.011)$ & $(0.006)$ & $(0.108)$ & -4.065 \\
Baseline controls & YES & YES & YES & YES \\
Year FE & YES & YES & YES & YES \\
Country FE & YES & YES & 94,954 & 0.187 \\
\hline Observations & 94,954 & 94,954 & 0.122 & 94,954 \\
R-squared & 0.186 & 0.262 & 0.13 \\
\hline
\end{tabular}

Robust standard errors (clustered by the survey clusters) in parentheses; ${ }^{* * *} \mathrm{p}<0.01,{ }^{* *} \mathrm{p}<0.05,{ }^{*} \mathrm{p}<0.1$

Table 3: Chinese aid and ethnic identification: variation across in- and out-group

VARIABLES

Ongoing
Future
In-group
In-group*ongoing

Diff ongoing-future

F test: ongoing-future $=0$

$p$ value of $F$ test ongoing-future $=0$

Diff (ongoing+In-group_ongoing)-future

F test (ongoing+ In-group_ongoing)-future $=0$

$\mathrm{p}$-value of $\mathrm{F}$ test (ongoing+ In-group_ongoing)-future $=0$

Observations

R-squared

Robust standard errors (clustered by the survey clusters) in parentheses; ${ }^{* * *} \mathrm{p}<0.01,{ }^{* *} \mathrm{p}<0.05,{ }^{*} \mathrm{p}<0.1 ;$ All regressions include baseline controls and year and country fixed effects.

\section{(1)}

(2)

$-0.008^{*}$

$(0.005)$

$-0.031^{* * *}$

(0.011)

$-0.019^{* * *}$

$(0.004)$

(0.005)

$-0.031^{* * *}$

(0.011)

$-0.016^{* * *}$

$(0.005)$

$-0.017^{* *}$

(0.008)

$0.0225 \quad 0.0252$

$4.693 \quad 9.116$

$\begin{array}{ll}4.693 & 9.116 \\ 0.0303 & 0.00254\end{array}$

.0082

0.51

0.4772

90,626

$\begin{array}{ll}90,626 & 90,626 \\ 0.029 & 0.030\end{array}$

2 


\begin{tabular}{|c|c|c|c|c|c|c|c|c|}
\hline VARIABLES & $\begin{array}{c}\text { (1) } \\
\text { High ethnic } \\
\text { identity sample }\end{array}$ & $\begin{array}{c}\text { (2) } \\
\text { Low ethnic } \\
\text { identity sample }\end{array}$ & $\begin{array}{c}3) \\
\text { High ethnic } \\
\text { inequality sample }\end{array}$ & $\begin{array}{c}4) \\
\text { Low ethnic } \\
\text { inequality sample }\end{array}$ & $\begin{array}{c}\text { (5) } \\
\text { Urban sample }\end{array}$ & $\begin{array}{c}6) \\
\text { Rural sample }\end{array}$ & $\begin{array}{c}7) \\
\text { High internet } \\
\text { sample } \\
\end{array}$ & $\begin{array}{c}(8) \\
\text { Low internet } \\
\text { sample }\end{array}$ \\
\hline Ongoing & $\begin{array}{l}-0.010 \\
(0.008)\end{array}$ & $\begin{array}{l}-0.007 \\
(0.005)\end{array}$ & $\begin{array}{c}-0.028^{* * *} \\
(0.006)\end{array}$ & $\begin{array}{c}0.009 \\
(0.007)\end{array}$ & $\begin{array}{c}-0.016^{* * *} \\
(0.005)\end{array}$ & $\begin{array}{c}0.008 \\
(0.011)\end{array}$ & $\begin{array}{l}-0.008 \\
(0.005)\end{array}$ & $\begin{array}{l}-0.006 \\
(0.008)\end{array}$ \\
\hline Future & $\begin{array}{c}-0.057^{* * *} \\
(0.016)\end{array}$ & $\begin{array}{c}0.000 \\
(0.013)\end{array}$ & $\begin{array}{c}-0.058^{* * *} \\
(0.016)\end{array}$ & $\begin{array}{l}-0.013 \\
(0.015)\end{array}$ & $\begin{array}{l}-0.025^{*} \\
(0.013)\end{array}$ & $\begin{array}{l}-0.036^{* *} \\
(0.017)\end{array}$ & $\begin{array}{l}-0.022^{*} \\
(0.012)\end{array}$ & $\begin{array}{c}-0.056^{* *} \\
(0.023)\end{array}$ \\
\hline Difference ongoing-future & 0.0472 & -0.00711 & 0.0302 & 0.0222 & 0.00819 & 0.0441 & 0.0142 & 0.0499 \\
\hline$F$ test: ongoing-future $=0$ & 10.89 & 0.266 & 3.620 & 2.530 & 0.386 & 8.559 & 1.354 & 6.433 \\
\hline$p$ value of $F$ test & 0.000977 & 0.606 & 0.0572 & 0.112 & 0.535 & 0.00345 & 0.245 & 0.0113 \\
\hline Observations & 47,959 & 42,667 & 44,877 & 45,749 & 36,359 & 54,267 & 51,966 & 38,660 \\
\hline R-squared & 0.023 & 0.010 & 0.031 & 0.016 & 0.029 & 0.029 & 0.030 & 0.030 \\
\hline
\end{tabular}

Robust standard errors (clustered by the survey clusters) in parentheses; ${ }^{* * *} \mathrm{p}<0.01,{ }^{* *} \mathrm{p}<0.05^{*} \mathrm{p}<0.1$; All regressions include baseline controls and year and country fixed effects. 
Table 5: World Bank aid and ethnic identity

\begin{tabular}{|c|c|c|c|}
\hline VARIABLES & $\begin{array}{c}\text { (1) } \\
\text { Ethnic identity }\end{array}$ & $\begin{array}{c}\text { (2) } \\
\text { Ethnic identity }\end{array}$ & $\begin{array}{c}\text { (3) } \\
\text { Ethnic identity }\end{array}$ \\
\hline Ongoing & $\begin{array}{c}-0.013^{* *} \\
(0.005)\end{array}$ & $\begin{array}{c}-0.013^{* *} \\
(0.005)\end{array}$ & $\begin{array}{c}-0.011^{* *} \\
(0.005)\end{array}$ \\
\hline Future & $\begin{array}{c}0.038^{* * *} \\
(0.010)\end{array}$ & $\begin{array}{c}0.038^{* * *} \\
(0.010)\end{array}$ & $\begin{array}{c}0.038^{* * *} \\
(0.010)\end{array}$ \\
\hline In-group & & $\begin{array}{c}-0.007 \\
(0.005)\end{array}$ & $\begin{array}{c}0.000 \\
(0.009)\end{array}$ \\
\hline In-group*ongoing & & & $\begin{array}{l}-0.012 \\
(0.011)\end{array}$ \\
\hline Diff. ongoing-future & -0.0507 & -0.0502 & -0.0486 \\
\hline F test: ongoing-future $=0$ & 29.37 & 28.83 & 4.421 \\
\hline $\mathrm{p}$ value of F test & $6.22 \mathrm{e}-08$ & $8.21 \mathrm{e}-08$ & 0.0355 \\
\hline Diff (ongoing+In-group_ongoing)-future & & & -.0609 \\
\hline F test (ongoing+ In-group_ongoing)-future $=0$ & & & 21.45 \\
\hline $\mathrm{p}$-value of $\mathrm{F}$ test (ongoing+ In-group_ongoing)-future $=0$ & & & 0.0000 \\
\hline Observations & 69,255 & 69,255 & 69,255 \\
\hline R-squared & 0.029 & 0.029 & 0.029 \\
\hline
\end{tabular}

Table 6: Other bilateral aid and ethnic identities in Malawi, Nigeria, Senegal, and Uganda

\begin{tabular}{|c|c|c|c|}
\hline VARIABLES & $\begin{array}{c}\text { (1) } \\
\text { Ethnic identity }\end{array}$ & $\begin{array}{c}(2) \\
\text { Ethnic identity }\end{array}$ & $\begin{array}{c}(3) \\
\text { Ethnic identity } \\
\end{array}$ \\
\hline Ongoing & $\begin{array}{c}-0.028^{* * *} \\
(0.010)\end{array}$ & $\begin{array}{c}-0.026^{* * *} \\
(0.010)\end{array}$ & $\begin{array}{c}-0.026^{* *} \\
(0.010)\end{array}$ \\
\hline Future & $\begin{array}{c}-0.004 \\
(0.013)\end{array}$ & $\begin{array}{c}-0.003 \\
(0.013)\end{array}$ & $\begin{array}{c}-0.003 \\
(0.013)\end{array}$ \\
\hline In-group & & $\begin{array}{c}-0.038^{* * *} \\
(0.008)\end{array}$ & $\begin{array}{c}-0.037^{* * *} \\
(0.011)\end{array}$ \\
\hline In-group*ongoing & & & $\begin{array}{c}-0.002 \\
(0.015)\end{array}$ \\
\hline Diff ongoing-future & -0.0239 & -0.0232 & -0.0228 \\
\hline F test: ongoing-future $=0$ & 3.768 & 3.660 & 3.353 \\
\hline$p$ value of $F$ test ongoing-future $=0$ & 0.0524 & 0.0559 & 0.0672 \\
\hline Diff (ongoing+In-group_ongoing)-future & & & -.0248442 \\
\hline $\mathrm{F}$ test (ongoing+ In-group_ongoing)-future $=0$ & & & 2.17 \\
\hline p-value of $F$ test (ongoing+ In-group_ongoing)-future $=0$ & & & 0.1407 \\
\hline Observations & 28,806 & 28,806 & 28,806 \\
\hline R-squared & 0.023 & 0.024 & 0.024 \\
\hline
\end{tabular}

Robust standard errors (clustered by the survey clusters) in parentheses; ${ }^{* * *} \mathrm{p}<0.01,{ }^{* *} \mathrm{p}<0.05,{ }^{*} \mathrm{p}<0.1$; All regressions include baseline controls and year and country fixed effects. 


\section{Appendix}

Figure A1: Country share identifying in ethnic rather than national terms

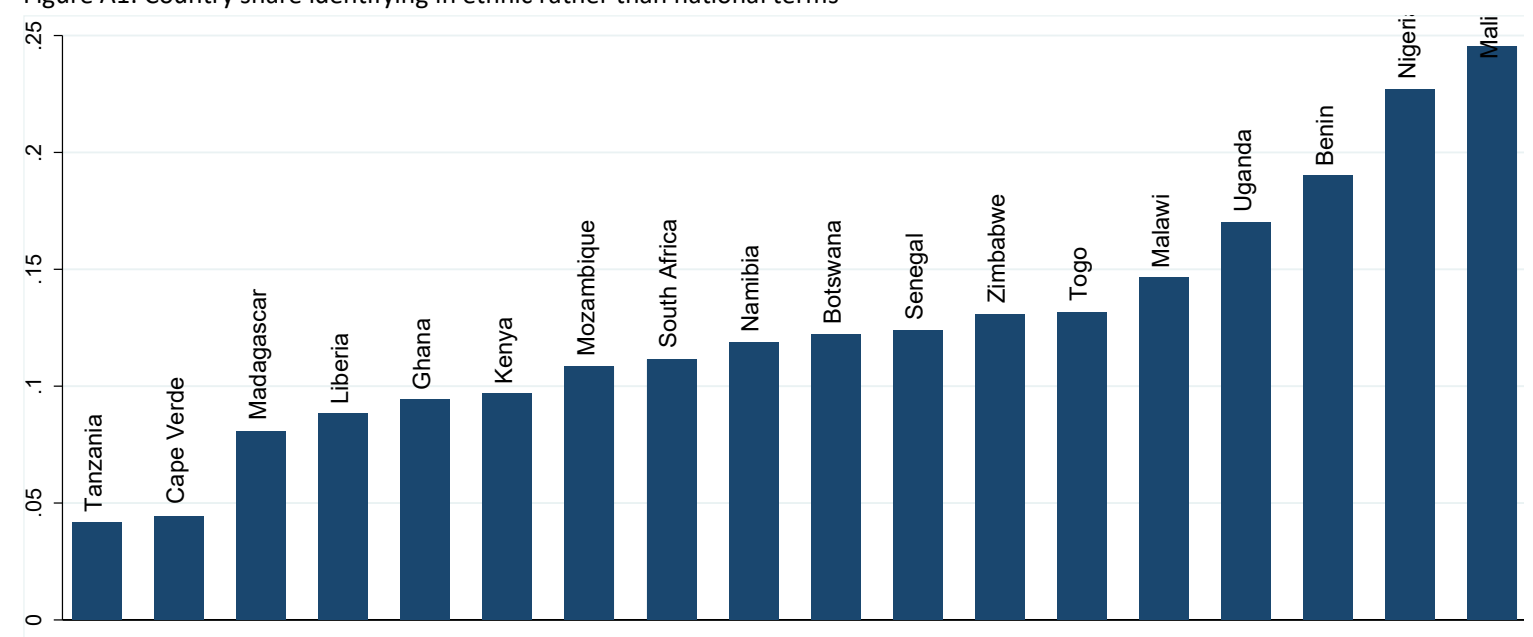

Figure A2: Timeline to illustrate estimation strategy

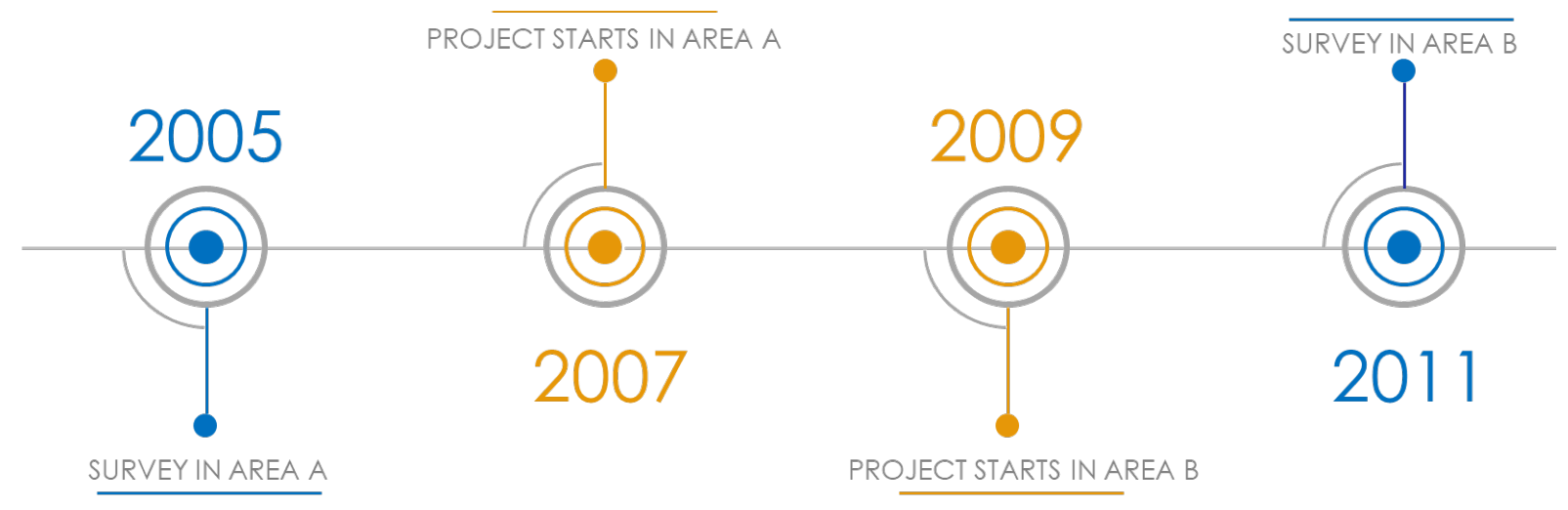




\begin{tabular}{|c|c|c|c|c|c|}
\hline Variable & Obs & Mean & Std. Dev. & Min & Max \\
\hline Ethnic identity & 94.954 & 0.134 & 0.340 & 0 & 1 \\
\hline Ethnic ordinal & 91.113 & 2.380 & 1.193 & 1 & 5 \\
\hline Ongoing25 & 94.954 & 0.190 & 0.392 & 0 & 1 \\
\hline Future25 & 94.954 & 0.034 & 0.181 & 0 & 1 \\
\hline Completed 25 & 94.954 & 0.046 & 0.209 & 0 & 1 \\
\hline Ongoing50 & 94.954 & 0.296 & 0.457 & 0 & 1 \\
\hline Future50 & 94.954 & 0.060 & 0.238 & 0 & 1 \\
\hline Completed50 & 94.954 & 0.089 & 0.284 & 0 & 1 \\
\hline Ongoing75 & 94.954 & 0.383 & 0.486 & 0 & 1 \\
\hline Future75 & 94.954 & 0.079 & 0.270 & 0 & 1 \\
\hline Completed 75 & 94.954 & 0.105 & 0.306 & 0 & 1 \\
\hline In-group & 94.954 & 0.164 & 0.370 & 0 & 1 \\
\hline In-group x Ongoing 25 & 94.954 & 0.028 & 0.164 & 0 & 1 \\
\hline Age & 94.954 & 36.361 & 14.405 & 18 & 130 \\
\hline Female & 94.954 & 0.499 & 0.500 & 0 & 1 \\
\hline Urban & 94.954 & 0.407 & 0.491 & 0 & 1 \\
\hline
\end{tabular}


Dependent variables, ethnic identification

Ethnic identification: Dummy equal to one if the respondent reports to identify more in ethnic than in national terms, i.e. providing a response falling in response category 1 or 2 to the following question (zero otherwise): "Let us suppose that you had to choose between being a [national ID] and being a [respondent's ethnic group]. Which of the following best expresses your feelings?" $1=\mathrm{I}$ feel only [Respondent's ethnic group], 2=I feel more [Respondent's ethnic group] than [national ID], 3=I feel equally [national ID] and [Respondent's ethnic group], 4=I feel more [national ID] than [Respondent's ethnic group] 5=I feel only [national ID], 7=Not applicable.

Ethnic ordinal: Ordinal variable based on the question described above, ranging from 1-5 and rescaled to be increasing in ethnic identification

Proximity to Chinese project sites

Ongoing25: Dummy variable equal to one if the respondent lives within $25 \mathrm{~km}$ of a site where a Chinese aid project is being implemented at the time of the interview, zero otherwise.

Ongoing50: Same as Ongoing25 but using a $50 \mathrm{~km}$ cut-off.

Ongoing75: Same as Ongoing25 but using a $75 \mathrm{~km}$ cut-off.

Future25: Dummy variable equal to one if the respondent lives within $25 \mathrm{~km}$ of a Chinese projects site where the implementation of the project had not yet started at the time of the interview and do not have any ongoing or completed project within this same distance, zero otherwise.

Future50: Same as Future25 but using a $50 \mathrm{~km}$ cut-off.

Future75: Same as Future25 but using a $75 \mathrm{~km}$ cut-off.

Completed25: Dummy variable equal to one if the respondent lives within $25 \mathrm{~km}$ of a completed Chinese project and do not have any ongoing project within this same distance, zero otherwise.

Completed50: Same as Completed25 but using a $50 \mathrm{~km}$ cut-off.

Completed75: Same as Completed 25 but using a $75 \mathrm{~km}$ cut-off.

In-group

In-group: Dummy variable equal to 1 if the respondent belongs to the same ethnic group as the country president at the time of the survey. Based on self-reported group affiliation using the question: "What is your ethnic community, cultural group or tribe?". coupled with externally compiled data on the ethnic background of the president at the time of the survey. For the ethnic groups of president, I consult at least two sources for each country, drawing most heavily on the compilation in Dreher et al (2015), when necessary updated with more recent data from other sources (e.g. encyclopedia britannica, wikipedia, aljazeera, washington post, africareview.com etc. ).

In-group*Ongoing: A multiplicative term between the in-group dummy and the Ongoing25 dummy.

Individual control variables

Female: Dummy variable equal to one if the respondent is female; zero otherwise.

Urban: Dummy variable equal to one if the respondent lives in an urban area; zero otherwise.

Age variables: Age in years and age squared.

Year dummies: Dummies for interview year, 2005-2015

Country dummies: Dummies for the 18 countries in the sample 